Sasa Milojevic

Nebojsa Pavlovic ${ }^{1}$

University Kragujevac

Faculty of Hotel Management and Tourism
SCIENTIFIC REVIEW ARTICLE doi:10.5937/ekonomika1701063M

Received: December, 25, 2016

Accepted: February, 13, 2017

\title{
ENTREPRENEURIAL SPIRIT OF RURAL TOURISM OF THE POMORAVLJE DISTRIC, CENTRAL SERBIA
}

\begin{abstract}
When it comes to the development of small and medium-sized enterprises in Serbia, special attention is given to the growth of small, family ones, mostly those which are involved in the food industry, which is a foundation for the development of rural areas. The plans of reviving Serbian village are a recurring topic. The reasons for this revival are the favorable geographic position, rich natural treasures, interesting tradition, and history. One must pay attention to the fact that $85 \%$ of the territory in Serbia has rural features and that $50 \%$ of citizens inhabits those areas. Through surveys, this paper explores how entrepreneurs manage their businesses in the countryside, especially in the field of tourism in the Pomoravlje District. 50 entrepreneurs, chosen by rendom sampling, were interviewed, and attention is given to hospitality companies, recreation centers or wineries which deal with grape processing and winemaking. What these entrepreneurs have in common is the fact that they run family enterprises, and that high tax rates and poorly equipped infrastructure in local communities are the basic obstacles for further development and growth of their enterprises.
\end{abstract}

Keywords: entrepreneurship, rural area, the Pomoravlje District, rural tourism, family enterprise

JEL classification: A14, F20, F60

\section{ПРЕДУЗЕТНИЧКИ ДУХ У СЕОСКОМ ТУРИЗМУ ПОМОРАВЉА, ЦЕНТРАЛНА СРБИЈА}

Када је у питању развој предузетништва малих и средњих предузећа у Србији, посебна пажна се придаје развоју малих, породичних предузећа, углавном у области прехрамбене индустрије, као основе за развој сеоских подручја. Стално се говори о плановима за оживљавање српског села. Разлог томе јесте повољан географски положај, богата природа, занимљива традиција и историја. Треба обратити пажюу на чињенииу да $85 \%$ територије Србије има руралне одлике и да на юој живи око 50\% становништва. У овом раду је путем анкетирања истражено пословање предузетника на селу у области туризма на територији Поморавског округа. Испитано је случајним узорком 50 предузетника са територије Поморавског округа, у питању су

\footnotetext{
${ }^{1}$ racapn@gmail.com
} 
угоститељско-смештајни објекти, рекреативни центри или винарије које се баве прерадом грожђа и производюом вина. Заједничко већини предузетника је да послују као породични бизнис, а високе стопе пореза и слабо уређена инфраструктура у локалним заједницама јесу основне препреке за даље напредовање и развој ових предузетника. У даљем тексту биће наведене и испитане хипотезе и биће обрађени добијени резултати.

Кључне речи: предузетништво, рурално подручје, Поморавски округ, сеоски туризам, породични бизнис

\section{Introduction}

Every area in Serbia can be divided into rural or urban according to legal regulations, but they can also be classified according to different features, such as population, statistical characteristics, and the number of agricultural population (Mitrović, 2015). To put it simply, the rural areas are those which are not urban. In Serbia, there are around 6000 of such areas. After World War II and up until today, a vast number of migrations from villages to cities have occurred. The biggest decline of population in rural areas occurred between 1961 and 1971 (Stevanović, 2006). What characterizes these areas are the unfavorable age structure and depopulation.

The objective of this research is to determine the importance of entrepreneurship in the Serbian village, as well as the impact of this phenomenon on the improvement of rural areas, which would aid in declining the number of migrations from village to cities. In order to abet the development of entrepreneurship in the rural areas of the Pomoravlje District, it is necessary to determine the current state of their development, establish the causes of negative and positive impacts on it and, lastly, ascertain the future directives for their development which would help these areas improve. The limiting factors of the entrepreneurial growth in rural areas are poor transport infrastructure, the lack of interest of travel agencies in promoting natural and cultural heritage, low quality of service, and the lack of skilled staff who specialize in the coordination of entrepreneurial growth in rural areas. It is estimated that around $30 \%$ of tourists in the world opt for this kind of tourism because they are eager to discover new areas, different customs, and cultures, and to experience a holiday in the countryside (Mitrović, 2015). The creation of small and medium-sized enterprises in the countryside would revive these areas and offer a solution for those who want to escape from the daily grind. These kinds of enterprises represent the pillars of economic growth in one country. Agricultural households would offer their tourists the sense of calmness, freedom, and relaxation, some fresh air, preserved nature, and also bona fide Serbian cuisine. With the significant changes in tourism in the last couple of years, there has been a surge in demand for alternative forms of tourism, and therefore for rural tourism.

In accordance with the set objectives of this research, the paper proposes the following hypotheses:

$\rightarrow$ H1: The rural areas of Serbia represent potentials for the development of rural tourism in Serbia. 
$\rightarrow \mathrm{H} 2$ : The entrepreneurial growth in rural areas can contribute to economic growth, increase standard and quality of living for the population in the Pomoravlje District.

$\rightarrow$ H3: The analysis of work of the entrepreneurs in the Pomoravlje District reveals the current state and how the local self-governance body and Serbia could encourage the entrepreneurs to base their work in the rural areas.

\section{Literature Review}

Rural areas in Serbia are depopulated and are constantly losing population, and the average age of those living there is above 60 (Strategy of Tourism RS, 2005). The availability of able-bodied and educated people in the countryside is the main prerequisite for the entrepreneurial growth and for the creation of tourism in villages. The most appropriate definition of entrepreneurship, which would fit into the context of development of rural areas, is a broad one which perceives entrepreneurship as: "the force for resource mobilization which behooves it to fulfill the needs of the market", "the capability to make and build something from scratch" (Gajić, M., Gajić A.,Stevanović, 2008). Lately, in Serbia, there has been a gradual development of a product of rural tourism which is diverse in order to satisfy every need. In the Western Serbia, this product is the restoration of old rustic Serbian houses, while in Vojvodina the so-called Salaš tourism is widely recognizable as a typical rural experience of that region. This product provides travel agencies with rural areas, hot springs, rivers or lakes, and presents its tourist with traditional hospitality and life values of the local population. It also represents the steppingstone for economic growth and improvement of the standard of living in rural communities, on the basis of sustainable development and preservation of natural resources (Strategy of Tourism RS, 2005).

The significance of entrepreneurship is seen by taking a closer look at the creative ability of individuals or groups that run the enterprise to produce new things. They are characterized by a special kind of behavior that involves: taking initiative, taking the business risk, possessing business creativity, ability to organize and come up with innovations for business activity in all aspects which require that (Radović Marković 2007). The concept of local entrepreneurship that deals with rural tourism could be based on the fight against spontaneous entrepreneurship programs, regardless of the strategic guidelines, production of a wide variety of development projects with projects for investment, suggestions for advancement of entrepreneurship at the local level, through state and local community activities (Jakovljević, 2011). It is essential to emphasize that entrepreneurship in rural areas does not differ particularly from that in urban areas. Entrepreneurship in rural areas involves the discovery of unique joint resources, inside or outside the field of agriculture. This can be achieved by expanding the basis of the agricultural household so as to include the entire nonagricultural use of available resources, which can be realized by any kind of enormous change in soil usage or different production levels from that which is heavily based on agriculture. Thus, an entrepreneur in the rural area is someone who is willing to remain in such environment and contribute to the production of local goods. For this reason entrepreneurship in rural areas is founded on a close-knit community and is 
characterized by strong family ties and relatively strong influence on the surroundings (Gajić, 2014; Pavlovic, Krstić, 2016).

The economic structure of rural areas in Serbia is still heavily based on natural resources depletion. The traditional, mono-functional agriculture is widespread and Serbia is one of the agrarian societies of Europe. Heterogeneity of natural resources, private land ownership, and experience with business cooperation, which are some of the prerequisites for diversification and development of rural economy, aren't used sufficiently (Bogdanov, 2007). In order to achieve the expected effects of rural tourism, planned encouragement and functional organization are necessary in order to develop tourist offer. Apart from this, rural tourism product can be locally controlled, based on authenticity and promotion which highlights realistic expectations and use of the product. All this would lead to the faster development of rural tourism in Serbia, which is currently bellow real potentials (Gašić, Perić, Ivanović, 2015). Citizens from the urban areas spend a lot of time in the rural areas of Serbia, and for them, the village is a cultural framework where life differs from their everyday one in the city. The bearers of economic growth of rural areas are indeed enterprises which prove their quality with competitive advantage and improvement of position on the market (Avlijaš, 2008).

Lack of funding, the economic crisis in Serbia, reduced number of tourists and inadequate infrastructure are some of the factors which have influenced the development of entrepreneurship in rural areas. Because of these factors, the state is required to provide incentives which would help entrepreneurs develop in the field of rural tourism and help them with their businesses. Programs for support of agriculture and village in Serbia involve a wide variety of support measures, including grants for buying farm equipment, maintenance of mechanics, purchasing livestock, cultivating crops and similar (Bogdanov, 2007). Small and medium-sized enterprises and the government adopt two different perspectives when it comes to supporting services. From the perspective of SMEs, support services lower the costs of movement for SMEs, enabling them to have bigger funds, which in turn allows them to use that revenue differently. On the other hand, those services are justified for the government because the tax rates are higher, which in turn lowers unemployment in rural areas and increases economic growth through smart investment (Avlijaš, 2008).

For the development of rural areas to commence, it is necessary to engage and educate the local citizens, to come up with strategic plans on a local level, and to form local work groups or development groups (Lazović, 2004). The role of the state would be reflected in co-financing the development plans which are related to the improvement of infrastructure and basic living conditions, which is the prerequisite for the development of rural tourism (Tourism Development Strategy RS, 2006). The best example of entrepreneurship in the countryside is the creation of small and medium-sized enterprises in the food industry (Ilić, Vujičić, Mihić, 2014). Tourism needs agricultural products during the year, while agriculture needs consumers. 


\section{Entrepreneurship in the rural area of the Pomoravlje District}

The Pomoravlje District contains 6 municipalities in the central part of Serbia; they are settled around the Great Morava River: Paraćin, Ćuprija, Jagodina, Rekovac, Svilajnac, and Despotovac (www.pomoravski.okrug.gov.rs). It stretches over $2614 \mathrm{~km}^{2}$ and has a population of 242931 in 191 neighborhoods, 6 of which are urban and 185 rural areas (www.popis2011.stat.rs). According to the data of Statistical Office of the Republic of Serbia, during the year municipalities, Paraćin and Jagodina have the highest percentage of tourists, both local and foreign (www.stat.gov.rs).

These two municipalities are the largest in the Pomoravlje District. Paracin stretches over $542 \mathrm{~km}^{2}$ and contains 34 villages, while Jagodina stretches over $470 \mathrm{~km}^{2}$ and contains the impressive number of 53 villages. European route E-75 runs through these two municipalities, so all these villages are easily accessible to tourists. A doubletrack railway that connects southern Europe and Asia with central Europe runs through these areas. The thing that attracts tourists to visit these areas, besides the fact that they are easily accessible and have a good geographic position, is history, culture, and the considerable number of rural households ready to host tourists, numerous cultural and historical monuments and an array of events such as: Meeting of Villages, Morava, my Sea, Convocation in Levač, Bean Festival...

The offer should be directed to the needs of people who live in the city, distancing them from stress and pollution. The services should include hunting, fishing, rafting, familiarizing tourists with wildlife, cultural and historical monuments and life in the countryside. The villages of this area provide a vast number of activities, ranging from a stroll through the forests and orchards, to cycling and horseback riding, to hunting and fishing, collecting medicinal herbs, mushrooms, and forest fruits. Tourists can get acquainted with old crafts, and also with agronomy and breeding.

\section{Research methods}

This research uses an analysis which entails the process of determining the state of small enterprises and entrepreneurs who work in the Pomoravlje District, and who impact the development of rural tourism. Research was conducted in the period from spring to autumn 2016, with the aim of making graduate master work. From the total of 62,50 entrepreneurs from these areas responded to 26 questions from the questionnaire either through surveys or formal and informal interviews. The majority of questions (18 out of 26 questions) are closed-ended ones, and the respondents have to circle one or more answers or rate the given answers from the Likert scale from 1 to 5 , where 1 represents the lowest and 5 the highest mark. Most answers are already given, while a particular number of questions ( 8 out of 26 questions) require a written answer. The first part of the questionnaire deals with the basic information about the company, followed by questions which are connected to the founder, CEO/entrepreneur and which help to compile the information about them. The next section is information about business, i.e. plans, expectations, success so far, the aspects of the business that need to be advanced, as well as the main problems, obstacles, and influence of the global economic crisis on the business. The questionnaire also comprises of questions which refer to the information on 
the equipment and how old it is, the former and future plans for investments in it, as well as whether their enterprises have or are planning to introduce new quality management systems standards and certificates. The last part of the questionnaire represents the marketing aspect of a business. It refers to supply and demand, import and export, competitiveness, as well as the limiting factors on the market. This part also comprises of questions about enterprise funding. Therefore, by filling out questionnaires, interviewing founders or responding to Google Form survey, this research obtained results.

The important aspects which have an influence on the development of entrepreneurship in rural areas are identified in this research by using t-test. The effects of the measures taken in Serbia are examined with the help of inductive and deductive approaches. These measures are aimed at encouraging the entrepreneurship development in rural regions and this research has come to certain conclusions about their realization. The statistical method is used in order to easily group the data, arrange and compare the quantitative results of the research which are obtained by using appropriate techniques of data collection.

\section{Analysis}

The goal is to research for what business is the Pomoravlje District most suitable for and to suggest new ideas that could aid someone in starting a business which isn't as widespread in this District, and which would still attract tourists and generate income to these municipalities. This analysis explains the attitude of the country towards small and medium-sized enterprises in the rural areas, and also towards family enterprises. The primary objective of this research is to obtain a reliable analytical background in order to recommend incentives for entrepreneurship development, primarily for the small family enterprises in the countryside. The significance of the research is based on the fact that these kinds of enterprises establish the framework for economic growth of rural areas because they are the main bearers of employment, job creation and the leading participants in raising GDP.

The survey includes enterprises which mainly provide tourists with holidays in the countryside, a place to stay overnight and the taste of Serbian traditional cuisine. Also, they introduce their guests to culture and tradition of the rural region, as well as with natural and cultural heritage. The most predominated enterprises in the Pomoravlje District are the ones which work in grape production, winemaking and hospitality industry. From the total number of 50 questioned enterpreneures, $40 \%$ answered that this is their primary activity. These enterprises provide their guests the tour of vineyards and wineries, wine and fruit brandy tasting, as well as the traditional lunch in the winery. A slightly smaller number of enterprises operate in recreation and hospitality management; those are the new enterprises which, besides basic activities, include in their offer active rest and wellness. The list of respondents also includes Park Minijatura, the only enterprise whose activity is rural tourism. This enterprise possesses scale models of medieval Serbian monasteries, which are built in the ratio 1:17. In determining how long these enterprises operate, the majority of respondents opt for 10 years. Statistically, $66.7 \%$ of these enterprises are founded by a man who is also the owner and the Chairman of the Board, while $26.7 \%$ of the enterprises are in group ownership. When it comes to the number of employees, all the respondents have up to 50 employees and so they fall into the category of small enterprises, and $33.3 \%$ of them are family businesses. When 
asked whether they need a skilled workforce, $80 \%$ of participants answer that they do. And when asked whether there is an employee training program, 73.3\% of participants respond that there is, while rest of them said that there isn't. 93.3\% of participants operate on their own property. All the enterprises have purchased new equipment for their business and have invested in infrastructure in the last three years, so as to climb the market ladder and gain competitive advantage. The respondents agree that their business is directed to all the regions in Serbia, but also to the foreign countries because they want to attract tourists with their activities and custom offers. When asked what conditions are necessary in order to improve work, the entrepreneurs agree for the following order:

1. Improvement of infrastructure, road construction, interior design, proper lighting which can be achieved by the help of the local community ( $94 \%$ of the questioned enterpreneurs gave this answer);

2. Preservation of environment and natural heritage $(80 \%$ of the questioned enterpreneurs gave this answer);

3. Business incentives grants $(76 \%$ of the questioned enterpreneurs gave this answer);

4. Business internet regulation $(72 \%$ of the questioned enterpreneurs gave this answer);

5. Determining quality management system standards $(66 \%$ of the questioned enterpreneurs gave this answer);

6. Education of local people $(60 \%$ of the questioned enterpreneurs gave this answer).

In regards to the business intentions of the respondents in the following three years, $80 \%$ of them answer that they plan to expand their business, and $20 \%$ of them plan to maintain the same scope of work. The majority of entrepreneurs do not possess the quality management system standard, not even the basic ISO 9001 quality management system, which would direct the enterprise to improve performance. Four enterprises possess HACCP quality management system, which deals with food safety through analysis and control of chemical, biological and physical hazards from raw material production, procurement, and handling, manufacturing, and distribution. Out of 50 enterprises, only one has OHSAS 18001 quality system management, which is for occupational health and safety.

All the respondents are ready to aid their local communities by continuing to work and employ new, primarily young people. When asked whether they use any local community services, $60 \%$ of respondents answer that they do, while the rest of them don't. During the assessment of the local self-governance body, the majority of them, $39.6 \%$ to be exact, marked them with 4. The highest mark is given to the local self-governance body in Jagodina, while the lowest to Despotovac. When it comes to tax rates, the majority of respondents, $33 \%$ to be exact, marked it with 3. Entrepreneurs from Jagodina are satisfied with tax rates and this municipality has the highest marks. The lowest mark is given to Despotovac for its high tax rates which entrepreneurs have to pay. The results of infrastructure maintenance are devastating because $40.6 \%$ of respondents mark it with 1 , while no one marked it with 5. Percentage wise, $86.7 \%$ of respondents believe that the global economic crisis in the country affects their business, but they haven't yet come across the need for layoffs. All of the respondents say that their products and services are intended to all the local tourists, but 
also foreign ones. $60 \%$ of the respondents buy their goods from the local community, while $40 \%$ of them buy their goods on a foreign market. When it comes to supporting in enterprises, the partakers select promotion as the one which is used the most, then business connections, market research, IT support, innovations and quality management system standards, while consulting is the least used. When asked about funding, $80 \%$ of them have independent sources of funding in the Pomoravlje District, while the remaining 20\% use external sources, such as bank loans, foreign loans, loans from state institutions, guarantees, financial leasing, donations and lastly they borrow from their friends.

\section{Discussion}

The first hypothesis of the article is that the rural areas of Serbia represent potentials for the development of rural tourism in Serbia This analysis proves that. The results of $t$-test show that $\beta=0.74$ and $t=3.84$. It has been determined that the development of rural tourism affects agricultural households and the local community, the prosperity of undeveloped regions, employment of the members of the household, promotion of handicrafts, preservation of customs and old crafts.

The hypothesis that entrepreneurship development in rural areas can aid economic growth, increase standard and quality of living of the population in the Pomoravlje District is true $(\beta=0.66, t=2,54)$. As stated in the "Entrepreneurship as an economic force in the development of rural areas in Serbia" (Gajić, 2014), entrepreneurship in rural areas is viewed as means for employment, while the residents in the countryside perceive it as an instrument for raising the standard of living. Also, women view it as a potential for employment close to home, which would bring about independence for them.

The analysis of entrepreneurs' work in the Pomoravlje District proves the last hypothesis, about how the local self-governance body and the state can encourage entrepreneurs to base their work in the rural areas. The people will continue to live in the rural areas if they are given jobs and if they generate income for their own family business. The results show that $\beta=0.46$ and $\mathrm{t}=3.02$. By developing the rural areas, conditions for balanced regional development are met .

The tourists expect that the rural areas will revive the rural spirit and landscape, possibility to watch rural activities and participate in them, provide unique food and beverages from those areas. As the group of authors in the Economic Horizon volume 8 state, the things that interfere with the entrepreneurship development in the countryside are small properties and unregulated cadastre; obsolete technology; insufficiently organized market; insufficient subsidies; low productivity; the lack of skills which are needed in the modern agriculture. The number of entrepreneurs needs to be greater in order to accelerate economic development in rural areas. A small number of people in the countryside need to unite and start a family business. Primarily, they need the help of the country and local community. The local communities should be given more funds, but also complete authority so that they can end economic stagnation by improving local development policy. A group of authors for Executive Newsletter in the paper Development of Rural Tourism in the Republic of Serbia stress that in order to bring about expected effects of rural tourism, it is necessary to encourage the rise of tourist offer of the village, that the product is authentic and promotes the given area. 
The environment has the biggest impact on entrepreneurship. The formation of supportive community, which is achieved by educating the local population about the positive influences of a family business, impacts the development of rural area. There are institutions that deal with this issue in Serbia and that try to help future entrepreneurs expand managerial skills and knowledge. Those are Centre for Organic Production, Centre for Promotion of Entrepreneurship, Centre for Socially Responsible Entrepreneurship, Affirmation and Development Centre. If the Serbian government does not strive to raise awareness of its nation of possibilities for better life and income through entrepreneurship development in rural areas, then people need to do so themselves, by uniting with the local self-governance body. The beginning of this idea would bring about the understanding that it would raise the standard of living. Agricultural households would be enlisted, they would renovate their houses and gardens, thus revive the environment. The neighboring municipalities would follow in their footsteps, and soon the entire Serbia would "understand what it is going on".

This paper analyzed entrepreneurship in the Pomoravlje District. The topic hasn't been researched before and it is difficult to find information which depicts the state of entrepreneurship in this area. The businesses of entrepreneurs are analyzed through the survey. They all have come to an agreement that this is a suitable area for someone to start a business in, primarily it is suitable for hospitality and recreation industry which would promote the natural and cultural heritage of the Pomoravlje District, and which would attract tourists.

\section{Conclusion}

Serbia has excellent conditions to develop rural tourism because of preserved nature, biodiversity, landscape diversity, favorable weather and numerous hydrographic resources. Cultural values and goods include cultural monuments of exceptional importance, diverse rural areas, and gardens. Rural tourism is important for sustainable development of rural areas, which abets the preservation of local identity, tradition, and customs; it protects the environment, strengthens the traditional and organic farming and helps the development of rural areas based on sustainable development. Also, rural tourism raises awareness of the local population about the economic and cultural value of natural and cultural sites. The important requirement for the protection and sustainable use of biodiversity is the involvement of communities in the development of rural areas. Entrepreneurship in rural tourism is a relevant factor, but without any state financial aid programs, the development will not be successful. The support of entrepreneurs in rural tourism should be direct (aids, subsidies, grants) or the country should invest directly in them (shared capital). The involvement of different state bodies and institutions which will financially assist the development of the program for rural tourism is of paramount importance. Also, it is important to encourage cooperation of agricultural households by strengthening the existing and creating new societies. All three hypoteses (H1 The rural areas of Serbia represent potentials for the development of rural tourism in Serbia; H2: The entrepreneurial growth in rural areas can contribute to economic growth, increase the standard and quality of living for the population in the Pomoravlje District; and H3: The analysis of work of the entrepreneurs in the Pomoravlje District reveals the current state and how the local self-governance body and Serbia could encourage the entrepreneurs to base their work in the rural areas) have been accepted according to the results of this research. 
The development of entrepreneurship in these areas would stop migrations to urban areas and would revive Serbian village, culture, and tradition.

\section{References}

Avlijaš, R. (2008). Menadžment i preduzetništvo malih i srednjih preduzeća, Univerzitet Singidunum, Beograd.

Bogdanov, N. (2007). Mala ruralna domaćinstva u Srbiji i ruralna nepoljoprivredna ekonomija, Beograd.

Gajić, A. (2014). Preduzetništvo kao privredna snaga u razvoju ruralnih područja u Srbiji, Visoka poslovna škola strukovnih studija "Prof. Dr Radomir Bojović", Kruševac.

Gajić, M., Gajić, A., \& Stevanović, M. (2008). Preduzetništvo i oblici preduzetništva, Grafos Smederevska Palanka.

Gašić, M., Perić G., Ivanović, V. (2015). Razvijenost ruralnog turizma u RS, BizInfo (Blace), 6(2): 71-81.

Horwath Consulting Zagreb i Ekonomski fakultet Beograd, Ministarstvo trgovine, turizma i usluga, (2005).

Strategija turizma Republike Srbije, Prvi fazni izveštaj. From:http://gt.uns.ac.rs Retrived 10. november 2016.

Ilić, M., Vujičić, M., Mićić, V.(2006). Granska ekonomija, Ekonomski horizonti, 8(1-2): 89-105.

Jakovljević, S., (2011). Lokalno preduzetništvo i ruralni turizam, Ekonomski vidici 16(2): 391-403.

Lazović, O., (2004). Razvoj manje razvijenih regiona kroz razvoj ruralnog turizma i obezbeđenje održivog razvoja, Planiranje uređenja sela i ruralnih područja, Banja Vrujci.

Ministarstvo trgovine, turizma i usluga, (2006), Strategija razvoja turizma Republike Srbije. “Službeni glasnik RS”, br. 91/2006. From:htpp://mttt.gov.rs. Retrived 10. november 2016.

Mitrović, M., (2015). Sela u Srbiji, promena strukture i problemi održivog razvoja. Popis stanovništva, domaćinstava i stanova 2011. Popis poljoprivrede 2012. Republika Srbija, Republički zavod za statistiku, Beograd.

Pavlovic, N., \& Krstić, J. (2016). Preduzetništvo i menadžment,Univerzitet u Kragujevcu, Fakultet za hotelijerstvo i turizam, Vrnjačka Banja.

Petrović, G., \& Grujović, M. (2015). Povezanost i ekonomski značaj ruralnog turizma i poljoprivrede, Stručni rad, Kragujevac.

Radović Marković, M. (2007). Preduzetništvo: Proces i praksa, Magnus.

Stevanović, R., (2006). Migrantsko stanovništvo Srbije in: Stanovništvo i domaćinstva Srbije prema popisu 2002. godine, Beograd.

Todorović, M., \& Štetić, S., (2009). Ruralni turizam, Univerzitet u Beogradu, Geografski fakultet, Beograd. 